\title{
First three years of the ACM Student Chapter Maribor
}

\author{
Iztok Fister Jr. \\ University of Maribor \\ Faculty of Electrical Engineering and Computer \\ Science \\ Smetanova 17, 2000 Maribor \\ Slovenia \\ iztok.fister1@um.si
}

\author{
Niko Lukač \\ University of Maribor \\ Faculty of Electrical Engineering and Computer \\ Science \\ Smetanova 17, 2000 Maribor \\ Slovenia \\ niko.lukac@um.si
}

\section{Background}

The Association for Computing Machinery (ACM) is one of the largest associations for the Computer Science field in the world. In recent years, it has enabled the establishment of local student chapters, at a university or community level, besides already growing professional chapters. The Student Chapter ACM Maribor was officially founded in 2015, as the first such Chapter in Slovenia. The idea was born when Iztok Fister Jr. and Niko Lukač, who were graduate students, discussed the problem that undergraduate and graduate students of Computer Science programs did not collaborate enough. This was even more apparent due to the research fields of various laboratories at the Faculty. Furthermore, there was a lack of student workshops and conferences, which would connect students in Maribor. The
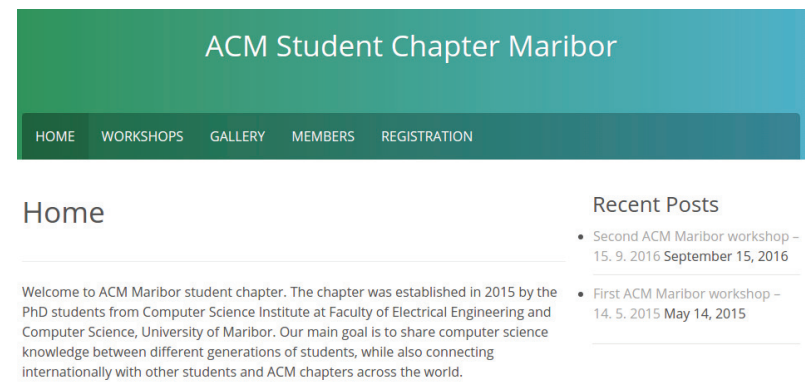

Q 2017 Jani Dugonik

Figure 1: Website of ACM Student Chapter Maribor.

possibility of meeting domestic students and students from other Slovenian universities, as well as participation in joint student conferences, was a big reason for the creation of this Chapter. Moreover, the ACM Student Chapter's members gain great benefits, such as complimentary subscription to ACM communications, a free acm.org email address, a full- year electronic subscription for the ACM's student magazine XRDS, and access to quarterly editions of the ACM Student Quick Takes (SQT) newsletter. The Chapter was created when 10 future members met together in order to elect the first Committee and set the goals for the Chapter in the inaugural year. In that meeting, the members discussed activities, where most of the words were dedicated to the first internal workshop that was planned to be organized in May, 2015. During the first meeting, members also discussed other aspects of the Chapter, such as financing, establishment of an internal mailing list, supporting and advertisement of the Chapter through all channels, especially a website (screen shoot is shown in Fig. 1). Table 1 presents the first elected student members in 2015. After a period of one year, new Chapter members were elected (Fig. 2), making the following appointments (Table 2). Future officials and members agreed that one year of being an official is not enough to implement greater ideas in the Chapter. The officials' period has, therefore, been extended to two years (by March, 2018).

\begin{tabular}{|l|l|}
\hline Position & Person \\
\hline \hline Chair & Iztok Fister Jr. \\
\hline Vice Chair & Niko Lukač \\
\hline Secretary & Denis Kolednik \\
\hline Treasurer & Danijel Žlaus \\
\hline Membership Chair & Sttefan Kohek \\
\hline Web Masters & Jani Dugonik, Uroš Mlakar \\
\hline
\end{tabular}

Table 1: First officials of the ACM Student Chapter Maribor (From March, 2015 to March, 2016).

\begin{tabular}{|l|l|}
\hline Position & Person \\
\hline \hline Chair & Uroš Mlakar \\
\hline Vice Chair & Stefan Kohek \\
\hline Secretary & Denis Kolednik \\
\hline Treasurer & Danijel Žlaus \\
\hline Membership chair & Dušan Fister \\
\hline Web Master & Jani Dugonik \\
\hline
\end{tabular}

Table 2: Second officials of the ACM Student Chapter Maribor (From March, 2016 to March, 2018). 


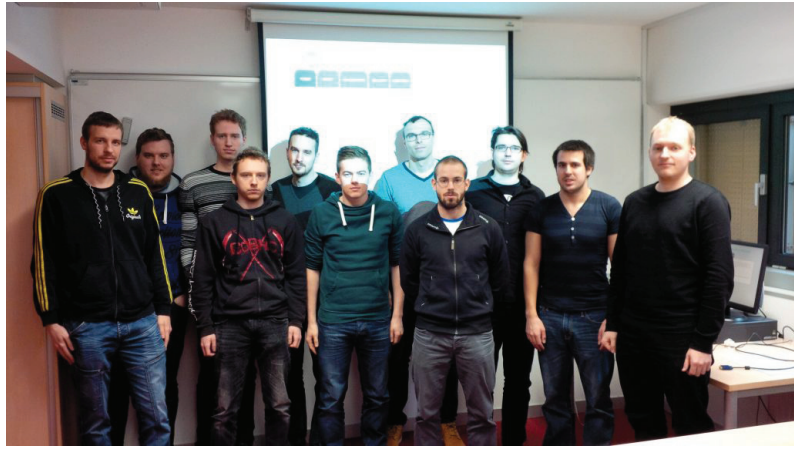

Figure 2: Member meeting in 2016 - From left to right: Miha Ravber, David Jesenko, Marko Bizjak, Matej Brumen, Denis Horvat, Robi Cvirn, Uroš Mlakar, Dušan Fister, Niko Lukač, Iztok Fister Jr., Štefan Kohek.

\section{Chapter activities}

Chapter activities can be grouped into five branches:

- Organization of internal workshops: The aim of these workshops is to organize a platform where members gather together and present their research work to other members or other Computer Science students interested in research. Until now, we have organized two workshops successfully (Fig. 3 presents members at the second workshop) where most of the members presented their research work. Presentations involved discussions, where new ideas were born for improving presented methods, or to provide an opportunity for research-based collaboration. Currently, the third workshop is in preparation and will be held in the second half of this year.

- StuCoSReC organization and promotion: Some members were participating in an annual StuCoSReC conference organization team. Chapter members were involved in the submitted papers' reviewing and editing process, as well as in the event's promotion.

- Recruiting activities: A major task of all members is to look for additional members that could join a Chapter and participate in Chapter activities. This was done in part with collaboration with the Institute of Computer Science, where the Chapter's banners were advertised on the Institutes' website (https://cs.feri.um.si/).

- Social events: The current idea of organizing them monthly does not bear fruit and, therefore, needs plenty of improvement. Especially, agreeing a proper time is one of the problems, since some members are employed in laboratories and occupied with project related research work. In a nutshell, social events should at least encompass some educational trips and invitation of ACM's distinguished speakers to deliver a talk. Currently, these activities are still in the planning process.

- Helping fellow students: In the first meeting, members concluded that all members (especially graduate students) should be able to help younger students.
Mostly, this part was very successful, since some student members organized educational workshops and prepared younger students to participate in programming contests, such as ACM-ICPC, the International Collegiate Programming Contest. Some experienced members also offered help for a conference paper preparation, i.e. for StuCoSReC.

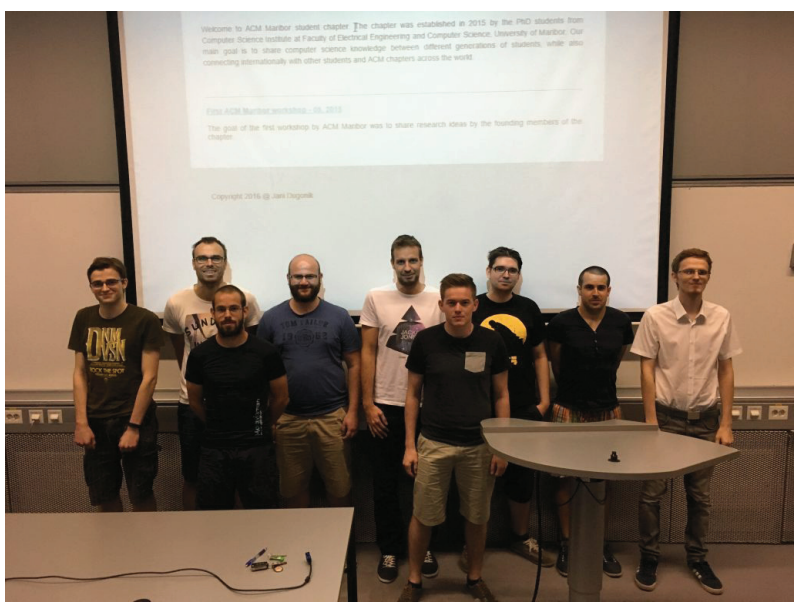

Figure 3: Second ACM Maribor workshop - From left to right: Tilen Škrinjar, Uroš Mlakar, Dušan Fister, Denis Kolednik, Miha Ravber, Robi Cvirn, Niko Lukač, Iztok Fister Jr., Primož Bencak.

\section{Conclusion}

There are many tasks for the future development of this Student Chapter. The most important work that waits for the members is recruitment related activities and increase of social events, especially from the other Faculties (e.g. Faculty of Economics, Faculty of Natural Sciences and Mathematics). Additionally, in order to organize more social activities, finding sponsors is a big priority.

\section{Acknowledgements}

We are very thankful to the Faculty of Electrical Engineering and Computer Science for their enthusiastically given support and the possibility to host our Chapter activities within the Faculty facilities. Especially, we much appreciate the support of Dean, Prof. Dr. Borut Žalik, who was also a driving force in the first baby steps of the ACM Chapter. We are also grateful to Prof. Dr. Marjan Mernik, the Head of the Institute of Computer Science, for helping with the promotional activities. 